Journal of Bangladesh Academy of Sciences, Vol. 38, No. 2, 219-224, 2014

\title{
EFFECTS OF QUAIL GENOTYPES ON HATCHABILITY TRAITS, BODY WEIGHT AND EGG PRODUCTION
}

\author{
M.S. ISLAM ${ }^{* 1}$, S. FARUQUE ${ }^{1}$, H. KHATUN ${ }^{1}$ AND M. N. ISLAM ${ }^{2}$ \\ Poultry Production Research Division, BLRI, Savar, Dhaka-1341, Bangladesh
}

\begin{abstract}
A study was conducted with four genotypes of quail, namely Japanese (J), White (W), Black (Bl) and Brown (Br) quail with the objective to know their hatchability traits, body weight and egg production performances. The parent males and females were maintained in cages for single pair mating through close breeding system for producing each generation. A total of 1866-day-old chicks comprising of 4 types of quail namely $\mathrm{J}, \mathrm{W}, \mathrm{Br}$, and $\mathrm{Bl}$ were hatched in a batch. The egg weight were $10.35 \pm 0.3,11.60 \pm 0.42,10.30 \pm 0.42$ and $9.78 \pm 0.65$ for $\mathrm{J}, \mathrm{W}, \mathrm{Br}$ and $\mathrm{B} 1$ respectively, which was influenced $(\mathrm{p}<0.05)$ by genotype. White genotype of quail is significantly better for egg weight, chick weight and chick: egg ratio than that of their counterparts. The highest hatchability of incubated eggs was found in Japanese quail genotype (71.01\%) and the lowest in Black (31.03\%). Significantly higher body weight was found in White and Black followed by Brown and Japanese quail genotype at different period of age. Significantly more number of eggs was obtained in Black (97.31) followed by Japanese, Brown and White respectively.
\end{abstract}

Key words : Genotype, Improvement, Body weight, Egg production

\section{INTRODUCTION}

In Bangladesh, quail was first introduced in 1980's for rearing mostly as a hobby. This was popular as a game bird since its domestication. Now popularity of quail rearing has been increased rapidly because of quick economic return. People are now much more interested for commercial quail production. Quail meat and egg are usually consumed by people throughout the country. Moreover, commercial quail production is established mainly for meat in Europe and for eggs in Japan (Minvielle et al. 1999). Meat type quail are marketed at simply 4 weeks of age in China. At this moment, meat type quail production is much popular than egg type quail production in Bangladesh. The demand of meat type commercial quail production is increasing day by day in our country. Poor people are interested reared quail on commercial basis due to lower initial investment and risk rather than commercial broiler farming. It is said that eight quail can be reared with the same investment and space for a chicken. But it is observed that most producers

* Corresponding author: <siraj_blri@yahoo.com>.

${ }^{1}$ Regional Station, BLRI, Bagabari, Sahjadpur, Sirajgonj-6770, Bangladesh.

${ }^{2}$ Director General, BLRI, Savar, Dhaka-1341, Bangladesh. 
confronted a problem to get high quality parents for producing good quality commercial quail chicks. Kesici et al. (1998) reported that selected Japanese quail at 5 weeks body weight was found genetic improvement in first generation with the heritability for body weight of 0.60 in females and 0.38 in males. However, Bangladesh Livestock Research Institute has taken a quail breeding research activity for reducing huge meat yield gap through commercial quail production in the country.

Selection is a powerful means for genetic improvement of poultry meat and egg production. Individual selection is particularly essential in selection experiments for body weight in quail. Individual selection is used based on breeding value for body weight at 5 weeks of age as the selection criterion. The continued selection for 11 generations based on 4th week body weight was increased from 48.9 to $49.7 \%$ in the selected lines of Japanese quail compared to their counterparts reported by Darkens and Marks (1998). However, quail breeding work maintaining accurate pedigree records for developing meat type quail genotype is scanty in Bangladesh. Therefore, the present study was undertaken to know the effects of four genotypes of quail on their hatchability traits, body and egg production.

\section{MATERIALS AND METHODS}

This study was conducted with four genotypes of quail, namely Japanese (J), White (W), Black (Bl) and Brown (Br) quail maintained in Poultry Production Research Division, Bangladesh Livestock Research Institute, Savar, Dhaka. The parent males and females were being maintained in cages for single pair mating through close breeding system for producing each generation. At least five generations of pedigree hatching were done to homogenize their genetic characters. Pedigree records are being kept by using commercially available leg bands to identify quail of all ages. For producing third generation (G3), parent quails of each genotype were selected from the 2nd generation (G2) on the basis of breeding value according to their 5th week body weight. Hatching eggs were collected from every single pen of the selected parent quails. A total of 1866day-old chicks comprising of 4 types of quail, namely $\mathrm{J}, \mathrm{W}, \mathrm{Br}$, and $\mathrm{Bl}$ were hatched in a batch for producing third generation. The chicks were housed and reared in brooder house in litter system up to 5 weeks of age. Then birds were shifted to individual cages in laying house and reared up to 24 weeks of age. All birds were fed on quail starter diet up to first 6 weeks of age. Then laying diet containing 24\% crude protein and $3000 \mathrm{kcal}$ $\mathrm{ME} / \mathrm{kg}$ were provided to the birds till to the end of study period. Farm bio-security and hygienic measures were maintained strictly to prevent outbreak of any diseases. Data on egg weight, hatchability, body weight of chick at first day, 2nd, 4th, 5th and 6th week of age, feed intake, mortality, egg production were recorded to study their productive and reproductive performances. 
Statistical analysis: All collected data were analyzed by general linear model (GLM) univariate procedure in SPSS (2002) Computer Program (version 11.5). Data were arranged for a completely randomized design (CRD) for analysis of variance (ANOVA). Least significant differences (LSD) for a parameter were used to calculate the significant difference among four genotypes of quail.

Statistical model : The following general linear statistical model was used to analyze the different parameters:

$\mathrm{Y}_{\mathrm{ik}}=\mu+\mathrm{g}_{\mathrm{i}}+\mathrm{e}_{\mathrm{ik}}$

where, $\mathrm{Y}_{\mathrm{ik}}$ is the dependent variable of the experiment;

$\mu$ is the overall mean;

$\mathrm{g}_{\mathrm{i}}$ is the effect of ith type $(\mathrm{i}=1-4)$;

$\mathrm{e}_{\mathrm{ik}}$ is the error term specific to each record.

\section{RESULTS AND DISCUSSION}

The effect of genotype for egg weight, chick weight and chick: egg weight ratios of quail are shown in Table 1. The egg weights were $10.35 \pm 0.3,11.60 \pm 0.42,10.30 \pm 0.42$ and $9.78 \pm 0.65$ for $\mathrm{J}, \mathrm{W}, \mathrm{Br}$ and $\mathrm{Bl}$ respectively, which were influenced $(\mathrm{p}<0.05)$ by genotype. Chick weight and chick: egg weight ratios of four genotypes of quails also significantly $(\mathrm{p}<0.001)$ influenced by genotype. White genotype of quail is significantly better for egg weight, chick weight and chick: egg ratio than that of their counterparts.

Table 1. Least squares means and standard error of means for egg weight, chick weight and chick: egg weight ratio of quail as affected by genotype.

\begin{tabular}{llll}
\hline \multicolumn{1}{c}{ Genotype } & \multicolumn{1}{c}{ Egg weight $(\mathrm{g})$} & \multicolumn{1}{c}{ Chick weight $(\mathrm{g})$} & Chick: egg weight ratio $(\%)$ \\
\hline Japanese & $10.35^{\mathrm{ab}} \pm 0.3(175)$ & $6.47^{\mathrm{a}} \pm 0.12(175)$ & $62.68^{\mathrm{a}} \pm 1.25(175)$ \\
White & $11.60^{\mathrm{a}} \pm 0.42(107)$ & $6.81^{\mathrm{a}} \pm 0.15(107)$ & $62.85^{\mathrm{a}} \pm 1.60(107)$ \\
Brown & $10.30^{\mathrm{ab}} \pm 0.42(107)$ & $5.95^{\mathrm{b}} \pm 0.15(107)$ & $58.23^{\mathrm{a}} \pm 1.60(107)$ \\
Black & $9.78^{\mathrm{b}} \pm 0.65(45)$ & $4.52^{\mathrm{c}} \pm 0.24(45)$ & $46.35^{\mathrm{b}} \pm 2.47(45)$ \\
Level of significance & $(\mathrm{p}<0.05)$ & $(\mathrm{p}<0.001)$ & $(\mathrm{p}<0.001)$ \\
\hline
\end{tabular}

These findings are similar to the results of Faruque et al. (2013) who reported that the chick: egg weight ratio of White genotype had higher percentage values $(65.25 \%)$ than the chicks in Japanese, Brown and Black. It was determined from the present study that chick weight increased with the increase of egg weight. This result is similar to the findings of Seker et al. (2004) who opined that the chick weight had shown a significant increase due to increasing egg weight. 
Table 2. Least squares means and standard error of means of different reproductive traits as affected by genotype.

\begin{tabular}{llll}
\hline \multicolumn{1}{c}{ Genotype } & \multicolumn{1}{c}{ Dead in shell $(\%)$} & \multicolumn{1}{c}{ Culled Chick $(\%)$} & \multicolumn{1}{c}{ Hatchability $(\%)$} \\
\hline Japanese & $27.03^{\mathrm{b}} \pm 1.83(175)$ & $4.23^{\mathrm{a}} \pm 0.50(175)$ & $71.01^{\mathrm{a}} \pm 1.83(175)$ \\
White & $42.44^{\mathrm{bc}} \pm 2.35(107)$ & $1.97^{\mathrm{bc}} \pm 0.64(107)$ & $55.01^{\mathrm{b}} \pm 2.34(107)$ \\
Brown & $43.18^{\mathrm{bc}} \pm 2.35(107)$ & $2.97^{\mathrm{ac}} \pm 0.64(107)$ & $54.95^{\mathrm{b}} \pm 2.34(107)$ \\
Black & $64.07^{\mathrm{a}} \pm 3.62(45)$ & $1.89^{\mathrm{bc}} \pm 1.00(45)$ & $31.03^{\mathrm{c}} \pm 3.62(45)$ \\
Level of significance & $(\mathrm{p}<0.001)$ & $(\mathrm{p}<0.001)$ & $(\mathrm{p}<0.001)$ \\
\hline
\end{tabular}

Figures in the parentheses indicate the number of observations. Least squares mean without a common superscript along the column differed significantly $(\mathrm{p}<0.05)$.

The reproductive traits of quail genotypes are presented in Table 2. The percentage of dead in shell was found significantly higher $(\mathrm{p}<0.001)$ in Black $(64.07 \%)$ than that of Japanese, White and Brown genotype, respectively. The highest culled chicks was observed in Japanese (4.23\%) followed by Brown (2.97\%), Black (1.89\%) and White $(1.97 \%)$, respectively. The percentage of dead in shell was the significantly highest but culled chicks significantly lowest in Black quail genotype. The probable reasons of present differences in hatchability traits of black quail genotype might be influenced by the different incubation factors. The hatchability of incubated eggs was 71.0, 55.01, $54.9 \%$ and $31.03 \%$ for Japanese, White, Brown and Black, respectively. The differences were significant $(\mathrm{p}<0.001)$ among the genotypes. The highest hatchability of incubated eggs was found in Japanese quail genotype (71.01\%) and the lowest in Black $(31.03 \%)$. This result is similar to the findings of Uddin et al. (1994) who reported that the different varieties of quail had the significant effect on the hatchability performance.

Table 3. Least squares means and standard error of means of different weight traits as affected by genotype.

\begin{tabular}{lcccc}
\hline Genotype & 2nd wk body wt. & 4th wk body wt. & 5th wk body wt. & 6th wk body wt. \\
\hline Japanese & $36.08^{\mathrm{b}} \pm 0.21(632)$ & $80.09^{\mathrm{d}} \pm 0.36(628)$ & $102.98^{\mathrm{b}} \pm 0.34(625)$ & $112.57^{\mathrm{c}} \pm 0.53(619)$ \\
White & $40.89^{\mathrm{a}} \pm 0.30(306)$ & $90.89^{\mathrm{a}} \pm 0.51(301)$ & $107.52^{\mathrm{a}} \pm 0.50(297)$ & $131.86^{\mathrm{a}} \pm 0.76(294)$ \\
Brown & $37.24^{\mathrm{c}} \pm 0.31(288)$ & $84.52^{\mathrm{c}} \pm 0.53(285)$ & $107.44^{\mathrm{a}} \pm 0.50(281)$ & $128.35^{\mathrm{b}} \pm 0.78(279)$ \\
Black & $40.15^{\mathrm{a}} \pm 0.50(114)$ & $86.37^{\mathrm{b}} \pm 0.86(109)$ & $108.84^{\mathrm{a}} \pm 0.83(104)$ & $131.90^{\mathrm{a}} \pm 1.24(102)$ \\
$\begin{array}{l}\text { Level of } \\
\text { significance }\end{array}$ & $(\mathrm{p}<0.001)$ & $(\mathrm{p}<0.001)$ & $(\mathrm{p}<0.001)$ & $(\mathrm{p}<0.001)$ \\
\hline
\end{tabular}

Figure in the parentheses indicate the number of observations. Least squares mean without a common superscript along the column differed significantly $((\mathrm{p}<0.05)$.

Table 3 shows that the body weight of four genotypes of quail at 2nd, 4th, 5th and 6 th week of age. Body weight of quails at 2nd, 4th, 5th and 6th week of age was significantly $(\mathrm{p}<0.001)$ influenced by genotype. The 6th week body weight was 112.57 
$\pm 0.53,131.86 \pm 0.76,128.35 \pm 0.78$ and $131.90 \pm 1.24 \mathrm{~g}$ respectively for Japanese, White, Brown and Black genotype. Significantly higher body weight was found in White and Black followed by Brown and Japanese quail genotype at different period of age. These values are in agreement with the results presented by Rahman et al. (2010) and Islam et al. (2011) who reported that body weight at different ages were significantly influenced by different types of color mutants or varieties of quails.

Least squares mean (LSM) and standard error of mean (SEM) of egg production upto 24 weeks of age are presented in Table 4. The total number of eggs up to 24th week of age was $94.52 \pm 0.56,84.23 \pm 0.67,87.05 \pm 0.69$ and $97.31 \pm 1.05$ respectively, for Japanese, White, Brown and Black genotype of quail and significantly ( $p<0.001$ ) differed among all genotypes. Significantly more number of eggs was obtained in Black (97.31) followed by Japanese, Brown and White, respectively. The present findings were mostly supported by Rahman et al. (2010), Homna et al. (1985) and Soliman et al. (2000) who opined that egg production had significantly differed by the different types of quail.

Table 4. Least squares means (LSM) and standard error of means (SEM) of egg production upto 24 weeks of age as affected by genotype.

\begin{tabular}{llc}
\hline Genotype & Egg production (no.) & Level of significance \\
\hline Japanese & $94.52^{\mathrm{b}} \pm 0.56(168)$ & \\
White & $84.23^{\mathrm{d}} \pm 0.67(117)$ & \\
Brown & $87.05^{\mathrm{c}} \pm 0.69(110)$ & $(\mathrm{p}<0.001)$ \\
Black & $97.31^{\mathrm{a}} \pm 1.05(48)$ & \\
\hline
\end{tabular}

Figure in the parentheses indicate the number of observations. Least squares means without a common superscript along the column differed significantly $(p<0.05)$.

\section{CONCLUSION}

It can be concluded from the present findings that the performance of white and black quail were superior for body weight and black for egg production. So these findings deserve more attention for continuing the ongoing research for producing a suitable meat or egg type quail genotype for the country.

\section{REFERENCES}

Darkens, J. R. and H. L. Marks. 1998. Divergent selection for growth in Japanese quail under split and complete nutritional environment. 1. Genetic and correlated responses to selection. Poultry Science 67: 519-29.

Faruque, S., H. Khatun, M. S. Islam and M. N. Islam. 2013. Conservation and improvement of quail. Proceedings of the Annual Research Review Workshop-2013, BLRI, Savar, Dhaka, Bangladesh. pp. 37-38. 
Homna, K., H. Oki and G. Watanabe. 1985. A plumage color mutation in Japanese quail associated with female specific sterility due to oviduct dysfunction. Japanese J. Animal Reproduction 31: 84-89.

Islam, M. N., M. S. Rahman and H. Khatun. 2011. Improvement of different color mutations of quails for meat production. Proceedings of the Annual research Review Workshop-2011, BLRI, Savar, Dhaka, Bangladesh. pp. 74-77.

Kesici, T., O. Kavuncu, M. M. Ozkan and M. A. Yildiz. 1998. Correlated responses of fitness to selection for 5 weeks of body weight in Japanese quail (Coturnix japonica). Abstracts of the $47^{\text {th }}$ Annual meeting of the European Association for Animal production. Lillhemmer 25-29 August, Norway, Poster G2. 36. pp. 30.

Minvielle, F., E. Hirigoyen and M. Boulay. 1999. Associated effects of the roux plumage color mutation on growth, carcass traits, egg production, and reproduction of Japanese quail. Poultry Sci. 78: 1479-1488.

Rahman, M.S., K. M. G. Rasul and M. N. Islam. 2010. Comparison of the productive and reproductive performance of different colour mutants of Japanese quails (Coturnix japonica). Proceedings of the Annual research Review Workshop-2010, BLRI, Savar, Dhaka, Bangladesh. pp. 50-56.

Seker, I., S. Kul and M. Bayraktar. 2004. Effects of parental age and hatching egg weight of Japanese quails on hatchability and chick weight. International J. Poultry Sci. 3(4): 259-265.

Soliman, F. N. K., A. Elsebai and M. Abaza. 2000. Hatchability traits of different colored Japanese quail eggs in relation to egg quality and female blood constituents. J. Egyptian Poultry Sci. 20(2): 417-430.

SPSS, 2002. SPSS computer program for windows 11.50 versions, USA.

Uddin, M. S., D. C. Paul and Q. M. E. Huque. 1994. Effect of egg weight and pre-incubation holding periods on hatcability of Japanese quail eggs in different seasons. Asian-Australian J. Animal Sci. 7: 499-503.

(Received revised manuscript on 12 October, 2014) 